\title{
International
}

Journal of Human Studies

Uluslararasi İnsan Çalışmalari Dergisi ISSN: 2636-8641

Cilt/Volume 1 Sayi/Issue 2 Yil/Year: 2018 Gönderim: 13-09-2018- Kabul: 02-11-2018

Conservative Modernism: An

Assessment Through Sabahattin Zaim's Point of View

\section{Muhafazakâr Modernleşme: Sabahattin Zaim Üzerinden Bir Değerlendirme}

\section{Serkan YORGANCILAR*}

\begin{abstract}
Even if definitions and limits of Turkish type of conservatism cannot be defined in a way which is different from the conservatism revealed in the sense of Western, it is a fact that Turkish conservatism also has its own distinctive features. For a long time, social scientists have been discussing on the definition of local and national conservatism differentiating from the definitions of Western conservatism. Within this scope, Turkish conservatism is taken form according to perception and life style of a certain group of people in pursuant of Turkish soil, Anatolian climate, specific belief of geography, culture and value structure. It is an incomplete process. Turkish conservatism proceeds in its own natural way.
\end{abstract}

In this article, the practices and discourses that Turkish conservatism asserts will be examined
Öz

Türk muhafazakârlığının tanım ve sınırları Batılı anlamda ortaya konulan muhafazakârlık tanımlarından farklı bir biçimde tanımlanamamıştır. Her ne kadar bu bir eksiklik olsa da Türk muhafazakârlığının kendine has belirgin özellikleri de içerisinde barındırdığı bir gerçektir. Batılı muhafazakârlık tanımlarından ayrışan yerli ve milli bir muhafazakârlık tanımı üzerinde uzun zamandır sosyal bilimciler tartışmalarını devam ettirmektedir. Bu kapsamda Türk muhafazakârllğı Türk topraklarına, Anadolu iklimine, coğrafyanın kendine has inanç, kültür ve değer yapisına uygun olarak, belirli bir grup insanın duyuş ve yaşam biçimlerine göre şekillenmektedir. $\mathrm{Bu}$ süreç henüz tamamlanmamış bir süreçtir. Türk muhafazakârllğı kendi doğal seyrinde ilerlemektedir.

\footnotetext{
* Serkan Yorgancılar, Öğretim Görevlisi, Gazi Üniversitesi, s.yorgancilar@gazi.edu.tr, Orcid: 0000-0002-8438-2012
} 
based on Sabahattin Zaim. Sabahattin Zaimis an enormously effective figure in the conservative imagination with his progressive and developmentalist modeling. Turkish conservatism, as an ideology, has developed a discourse through settling of modernization. However, the conservatism also shows a moderate approach to conservation of traditions and a more gradual modernization. In this context, Sabahattin Zaim constitutes a sample of a conservative modernization with his concrete practice examples particularly on finance, development and education.

Keywords: Conservatism, Modernism, Culture, Value, Education
Türk muhafazakârlığının modernleșme konusunda ortaya koyduğu pratikler ve söylemler üzerinden bir inceleme yapacağımız makalemizde Sabahattin Zaim üzerinden bir değerlendirmeye gidilecektir. Sabahattin Zaim muhafazakâr muhayyilede ilerlemeci ve kalkınmacı modellemeleriyle son derece etkin bir figürdür. Türk muhafazakârllğı bir ideoloji olarak modernleşme ile hesaplaşmak üzerinden bir söylem geliştirmiştir. Ancak muhafazakârllk gelenek ve göreneklerin korunması ve daha aşamalı bir modernleşmeye de 1 lımlı yaklaşmıştır. Bu kapsamda Sabahattin Zaim özellikle finans, kalkınma ve eğitim alanlarında yapmış olduğu uygulama örnekleriyle muhafazakâr bir modernleşme örneği oluşturmaktadır.

Anahtar Kelimeler: Mubafazakârlhk, Modernižm, Kültür, Değer, Sabahattin Zaim

\section{Giriş}

\section{Sabahattin Zaim'in Düşünsel İklimi}

Sabahattin Zaim hem akademik birikimi ve eğitimi ile ortaya koyduğu eserler hem de muhafazakâr kitlenin modernleşmesine yaptığı katkılar açısından incelenmeye değer bir isimdir. Makedonya göçmeni bir ailenin çocuğu olarak yetişme yıllarında farklı kültürlerle kurduğu temas onun gelecek yıllarda ortaya koyacağı çalışmaları da etkilemiştir. İstanbul Vefa Lisesi mezunu olup, Ankara Siyasal Bilgiler’i bitirmiş ardından Amerika'da akademik kariyerine başlamışır. Türkiye'ye döndükten sonra kısa bir dönem kaymakamlık görevinde bulunduktan sonra akademiye geçmiştir. Türkiye'nin sorunlarını yerinde görme ve insanlarla doğrudan temas etme yılları olan kaymakamlık dönemi onun düşünce iklimini anlamamız açısından önemlidir. Zaim'in ilk kaymakamlık yeri çekilen kura sonucunda Kâhta olarak belirlenmiştir. Ona göre, Kahta kaymakamlığ1 Türkiye'yi kurtarma yolculuğuna çıkışıt. Bu görev için yola çıktığında kendisini kutsal bir vazifeyle görevlendirilmiş bir misyoner gibi hissettiğini söylüyordu. (Zaim, 2008, s. 138)

Zaim'in Anadolu'nun bu ücra kasabasında edindiği tecrübeler hakkında yapmış olduğu yorumlar cumhuriyet aydınlarının kuruluş yıllarında Anadolu hakkında yapmış oldukları yorumlarla 
paralellik arz etmektedir. Hatıralarında Kahta'nın o günkü durumu ile ilgili uzun bir değerlendirme yazan Zaim, halkın dindar ama dini bilgiler bakımından cahil, şekle bağlı bir dindarlık yaşıyor olmalarını söylemesi ve buna benzer yorumlarda bulunması yukarıdaki görüşümüzü teyit eder nitelikteki düşünceleridir. Bu satırlar adeta Yakup Kadri'nin Yaban romanını hatırlatmaktadır. Zaim'in erken dönemlerinde böylesine bir değerlendirmeyi yapmış olması onun yetişme şekliyle ilgilidir. Çünkü Sabahattin Zaim, başta Ali Fuat Başgil olmak üzere hocaları olan Fındıkoğulları, Orhan Tuna ve Sabri Ülgener gibi önemli isimlerden ders almıs, eleştirel düşünceye açı, gelenek ve modernliğin kesiştiği bir noktada olan biridir. Aslında o sadece Kâhta halkının değil hocalarının da dindarlığını beğenmez. Hocalarının yetişme dönemlerinde uygulanan politikaların İslam'ı dışlamak isteyen bir atmosfer oluşturduğunu ve hocalarının da böylesine bir ortamda yetiştikleri için inançlı kimseler olmalarına rağmen hiçbirinin amelleri konusunda yeterince hassas olmadıklarını söyler (Zaim. 2008, s. 201). Evinin bulunduğu blokun bir ucunda Mahir İz Hoca, diğer ucunda Eşref Edip’in ikamet ettiğini (Zaim, 2007, s. 191) düşündügümüzde onun dini hassasiyetleri yaşama noktasinda gösterdiği özeni daha rahat anlayabiliriz.

Gençlik yıllarında Vefa Lisesi mensubu olarak eğitimini burada tamamlamış olması, onun gelişiminde önemli etkileri olmuştur. Dönemi itibariyle iyi bir eğitim sistemine sahip olan lise, öğretmenleri bakımından da şanslıdır. Nurettin Topçu'nun felsefe ve Reşat Ekrem Koçu'nun tarih derslerine girdiği Vefa lisesinin birçok hocası üniversiteden gelmekteydi. Yükseköğrenimini tamamladıktan sonra uzun yıllar başta Amerika olmak üzere birçok yabancı ülkede bulunmuştur. Bütün bunlar onun kişilik oluşumunu etkilemiş olmakla birlikte onun üzerinde en büyük etkiyi İskenderpaşa ve onun şeyhi Mehmed Zahid Kotku yapmıştır. Nakşibendiliğin bilişsel tarzını değiştiren Kotku, 1960’ların Türkiye'sinde sivil alanda etkin olmayı başarabilen ve dönemin yükselmekte olan İslami söylemlerinden çok farklı olarak devleti düşman görmeyen dini söylemiyle daha farklı bir insan modeli üretmekteydi. (Mardin. 2005, s. 48)

\section{Modernleşme Çabalarına Katkıları ve Batı Modernleşmesi Hakkındaki Görüşleri}

Yaşanan ve tamamlanmamış bir süreç olarak modernleşme, modernleşmiş toplumlar ve modernleşmekte olan toplumlara çok çeşitli olanaklar sunduğu kadar birçok gerilim ve krizinde kaynağ1 olmuştur. Modernleşme kavramı sınırsız biçimde tanımlanabilir bir kavram olsa da tarihsel olarak on yedinci yüzyıldan on dokuzuncu yüzyıla kadar Batı Avrupa ve Kuzey Amerika'daki toplumsal, ekonomik ve politik sistemlerde meydana gelen değişimin bir ürünü olarak gelişen, sonra diğer Avrupa ülkelerine ardından da on dokuzuncu ve yirminci yüzyılda Asya, Afrika ve Güney Amerika ülkelerine yayllan bir süreçtir (Einsenstadt, 2014, s. 11). Modernleşme süreci sonunda toplumsal yap1lar derinden etkilendi, geleneksel kurumlar eski önemlerini korumakta zorland, kentleşme ve göç gibi unsurlar sonrasında toplumsal değer yargıları aşındı ve yeni değer sistemleri üretildi. Ekonomik ilişkiler farklılaştı, çalışma biçimleri değişti, yeni finans sistemleri ile toplumsal yapılar yeniden inşa edildi. Bu süreçler sonrasında modern toplumların örgütsel yapısını belirleyen özellikler yenilendi. Buna göre işlevselliği olan çok sayıda kuruluş ortaya çıktı. Bütün bunların sonucunda beklenmedik biçimde geleneksel ve muhafazakâr hareketler güç kazandı (Berger. 2002, s. 16). İşgücünün bölünmesi sonrasında da birincil ilişkiler yerine uzmanlaşma esasına dayalı ikincil ilişkiler ortaya çıktı. 
Modernleşme süreçleri tüm dünyada farklı biçimlerde toplumları etkiledi ve dönüştürdü. Türkiye bu süreçlerden etkilendi ve Türkiye'nin de sosyo-ekonomik görünümü süreç içerisinde değişti. (Ahmad, 2007, s. 198)

Zaim, doğu ve batı arasında belirli farklılıklar olduğunu, bu farklılıkların doğru biçimde anlaşılmadan Türk toplumunda neden modernleşmenin istenilen ölçüde gerçekleştirilememiş olduğunun anlaşılamayacağını söyler. Ona göre, bizim Batıdan farkımız cemiyetimizin yapısından kaynaklanmaktadır. Sanayileşme, Osmanlı toplumunda 19. yüzyılda başladığını ve bir süre sonra inkıtaa uğradığını ifade eden Zaim cemiyet düzenimizin farklı olmasından dolayı Batı'da yaşanan modernleşme sancılarının bizde yaşanmadı̆̆ının altını çizer (Zaim, 2007, s. 14). Türkiye’nin modernleşme tarihi boyunca tartıştı̆̆ temel konulardan birisi olarak batı toplumları ile olan temel farklılı̆̆ımızın hangi unsur olduğu sorununun temeli meşrutiyet dönemi tartışmalarına kadar uzanmaktadır. Meşrutiyet dönemi İslamcılarına göre, batılılaşma ya da modernleşme Türk toplum yapısıyla uyuşmayan bir sürecin adıdır. Meşrutiyet İslamcıları batılılaşmayı, Hristiyanlığın bir sonucu olarak değerlendirirken batılılaşmayı savunanlara göre ise batılılaşma, sadece dinsel olgularla açıklanamaz. Batılılaşma onlara göre uygarlıktan sadece ilerlemeyi düşüncesini almak olarak algılanmamalıydı. Modernleşmeyi meydana getiren temel unsurlar benimsenmedikçe modernleşme gerçekleşemeyecekti. (Berkes, 2002, s. 416)

Sabahattin Zaim, Türkiye’nin kalkınmasının iktisadi açıdan ve eğitim açısından olmak üzere iki yönden gerçekleşmesi gerektiğine inanır. Ona göre, Türkiye'de eğitim ve iktisadi açıdan kalkınmayı İskender Paşa Camisi'nde Mehmet Zahid Kotku başlatmıştır. Elbette bu ifadenin abartılı olduğu düşünülebilir. Ve bu abartının kaynağı da Zaim’in şeyhi olarak gördüğü Kotku’ya olan aşırı sayg1sı gösterilebilir. Zaim’in bu sözünü başka bir biçimde anlayacak olursak, burada kast edilen mananın, sembolik bir değer taşıdığı düşünülebilir. Çünkü bir profesör olarak Zaim, Türk eğitim sisteminin geçirdiği evreler hakkında bilgi ve fikir sahibidir. İskender Paşa'nın eğitim ve iktisadi açıdan kalkınma hakkındaki düşünceleri, modernleşme ve batılılaşma tartışmalanının dışında, milli ve yerli unsurlara dayanarak, temel ahlaki dayanaklarını İslam ahlakı ve esaslarından alan, tasavvufi insan yetiştirme ve yaşama modeli doğrultusunda olması gerektiği hususlarında bir farklılık yarattığı şeklinde yorumlanabilir. Bu farklı söylemin, somut olarak, ortaya konulmaya çalışıldığ1 ilk deneme Gümüş motor fabrikasının kurulmasıdır.

1957’de Gümüş Motor fikrinin de ilk kez bu mecrada doğduğunu, bununla ilgili olarak 1963 yılında Mehmet Zahid Kotku'nun Almanya'da ziyaretler geçekleştirdiğini, bu ziyaretlerde de kendisine Zaim'in bizzat eşlik ettiğini hatıratından biliyoruz. Hatta bu seyahatle ilgili olarak Zaim hatıratında şöyle yazar: "Bir tarikat şeyhi motor sanayiyle ilgileniyordu. Hatz Motor Sanayinin defterine şunları yazdığını hatırlıyorum: "Dünyaları çok güzel, Allah iman nasip etsin”. Mehmet Zahid Kotku, hem tarikat şeyhi olarak hem de sanayileşme konusunda ortaya koyduğu tavırlarla Sabahattin Zaim üzerinde son derece etkili olmuş isimlerden biridir.

Gümüş Motorun kurularak üretime geçirilmesi muhafazakâr modernleşmenin Türkiye’de yapmış olduğu en somut ve belki de en ciddi işlerin başında gelmektedir. Muhafazakâr münevverler, Türkiye'de motor üretilmemesinde ve diğer birçok üretim alanında olduğu gibi bu alanda da dışa bağımlılıktan son derce rahatsızdı. Sabahattin Zaim gümüş motorun kurulma sürecinin somut olarak 
ortaya konulmasından sonra dindar iş adamlarının şirkete üye olmaya başladıklarını, işin asıl muharriki ve esas üstlenicisinin Topbaş ailesi olduğunu, projenin mimarın ise Necmettin Erbakan olduğunu ifade eder (Zaim, 2007, s. 279). Erbakan Hoca ile birlikte yürüttüğü işlerden birisi de TÜMOSAN Motor Fabrikasıdır. Zaim, TÜMOSAN'in ilk yönetim kurulu üyelerinden birisidir (KTO, 2005). Gümüş Motorun kuruluş aşamalarında büyük zorluklar yaşanmıştır. Zaim, Adnan Menderes’in bu oluşumu desteklediğini ve gerekli malzemelerin, bilgi ve patentin alınması için gerekli dövizi kendilerine sağlayan kişinin Menderes olduğunu söyler. Menderes’ten alınan döviz sayesinde Gümüş Motor'un kurucu kadrosu Fransa, Almanya, İngiltere ve Amerika'da görüşmeler yaptıklarını ama bütün görüşmelerin olumsuz sonuçlandığını, en son olarak Türk girişimcilerin Rusya’ya yönlendiğini Rusların da onları Çekoslovakya'da ki Skoda fabrikasına yönlendirdiklerini aktarır. Ancak, İstanbul Belediyesi’ne otobüs satan Skoda'da firması da kendilerine yardımcı olmaz. Yetkililer ise Skoda'ya eğer projeye gerekli teknik destekleri vermezlerse kendilerinden otobüs almayacaklarını bildirirler. Bunun üzerine Skoda geri adım atar ve Gümüş Motor için yardımcı olur. Gümüş Motor örneği üzerinden muhafazakârlığın kalkınmacı ve gelişmeci yanını analiz edebiliriz. Eleştirilerin aksine, böylesine bir üretim tesisi kurmuş olmak, dünyaya açık olmayı ve dünyayla rekabet edebilecek bir öz güvene sahip olabilmeyi göstermektedir. Böylesi bir durumda, yeni muhafazakârlığın modernleşmeyle kurduğu ilişki biçiminin meşrutiyet yıllarından beri sürmekte olan reddiyeci tutumu aşarak onunla bütünleşmeye başladığını söyleyebiliriz.

Modernleşmenin sadece sanayi ve iktisadi açıdan olamadığını, bunu destekleyecek ahlaki ilkelerin de bir zorunluluk olduğunu ifade etmenin dönemin bütün muhafazakâr düşünürlerinde görebiliriz. Örneğin Necmettin Erbakan Milli Görüş’ün maddi ve manevi kalkınmayı aynı anda yapacak bir hareket olduğunu ifade etmesi bu bakış açısının en tipik ifadesidir. Sabri Ülgener gibi düşünürler de modern kapitalist sistemin Türk toplumunda neden Batı toplumlarında ki gibi gelişmediğini analiz ederken her iki toplumun sosyo-kültürel farklılıklarının buna neden olduğunun altını çizer. Ülgener, Weber’in doğu toplumlarını geri bıraktığını iddia ettiği tüm saikleri reddederek, Osmanl1-Türk toplumsal yapısının batı toplumsal yapısından farklı bir gelişim çizgisi olduğu üzerinde durur. (Ülgener, 2015, s. 75)

Muhafazakâr düşünce batı düşüncesinin bir krize girdiğini ve batının bu krizden kurtulamayacağına inanmaktadır. Bu bakış açısına göre, dünyada sürmekte olan savaşlar, yıkımlar, şiddet olayları, ekonomik ve iktisadi buhranlar, ahlaki çöküntü gibi olumsuz giden tüm süreçler batı düşüncesinin çökmekte olduğu tezini güçlendirmektedir. Sabahattin Zaim Amerika'da eğitim görmüş, Amerikan sistemini çok iyi tanımış, Amerikan sisteminin güçlü yanlarının ülkemizde de uygulanması gerektiğini ifade etmiş ancak bütün bu olumlu görüşlerine rağmen o da batının kriz içerisinde olduğu nu düşünmektedir. Zaim, batı dünyasının bir kriz içerisinde olduğunu, kapitalist sistemin henüz çökmediğini ancak çok büyük zorlukları aşabilecek reçetelerinin bulunmadığını söyler. Buna ek olarak Marksizm’in zaten çöktügüünü de sözlerine ekler. Dolayısıyla insanlığın geleceğini “iyi insan” modeli üzerinden kurgulanacak bir İslam medeniyetinin omuzları üzerinde yükselmesi gerektiğine olan inancının altını çizer (Zaim, 2007, s. 30). Batı medeniyetinin krizi üzerine yapılan sayısız bilimsel çalışma bulunmaktadır. Ancak bunun tam tersi olan, batı düşüncesini zamanın şartlarına ve ruhuna uygun olarak yeniden ihya etme, ileri teknolojilerin ve tüketim ekonomisinin doğurduğu yeni şartlara cevap verme, başta çevre sorunları ve yoksulluk gibi tüm insanları ilgilendiren ortak sorunlara karşı 
çözüm önerileri üretebilme konusunda Batı'nın hala canlı bir medeniyete sahip olduğunu iddia eden çalışmalarda mevcuttur. Şiddete dayanmayan siyaset ahlakı, iktisadi ve sosyal hakların yeniden dağıtımı, değişen sorumluluk modelleri ve evrensel modellerin içselleştirilmesiyle batı dişı modernleşme tecrübelerinden de faydalanacak olan Bat1, küreselleşme sürecini de farklı tarzda atlatarak yeni bir sisteme evrilme çabalarını sürdürmektedir (Falk, 2001, s. 144-149). Dolayısıyla durum, muhafazakâr modernleşmecilerin yorumladığı kadar basit değildir.

Amerika'da ve yurt dışında uzun yıllar kalan Zaim, özellikle batıyla çok temas eden zenginlerin birçoğunun "formasyon" (Zaim, 2007, s. 16) bozukluğuna uğradığını söylüyor. Aslında diğer başka konuşmalarında ve hatıratının geneline baktığımızda formasyon bozukluğu olarak neyi kast ettiğini daha rahat anlayabiliyoruz. Ancak burada sorulmas1 gereken soru neden sadece "zenginlerde" bu formasyon bozukluğunun olduğunu düşündüğüdür. Kendi hatıratında, akademisyenlerin bat1 karşısında daha eleştirel ve dinamik bir tutum sergileyebileceklerini gösteren bir ayrıntı var. Amerika'da bulunduğu bir üniversitede (hangi üniversite olduğunu belirtmiyor) üzerinde gizli kaydı bulunan Federal Eğitim Kongresinin bir kitabında (kitap ismi de belirtilmiyor) mealen şu ibarelere rastladığını ifade ediyor: "Afrika yirmi birinci asrın kıtası sayılır. Bakir, zengin bir ülkedir ve Batı medeniyeti için çok önemlidir. Bu kıtada bizim için iki tehlike bulunmaktadır. Biri komünizm, diğeri İslamiyet. Ancak, İslamiyet Batı medeniyeti için komünizmden daha tehlikelidir. Zira biz komünizmi, başarılı olsa dahi bir takım maddi tedbirlerle bertaraf edebilir. Ama şayet yirmi birinci asrın kıtası olan Afrika’ya İslam girer ve hakim olursa bu kıta Batı medeniyeti için ilelebet kaybedilmiş olur”. (Zaim, 2007, s. 20)

Toplum, çeşitli tabakalardan oluşan sosyal bir gerçekliktir. Toplumsal yapıları dilediğimiz gibi değiştirme ve ona istediğimiz şekli verme konusunda sınırlı olanaklara sahibiz. Bu konuda Freyer, toplumun bizi bağladığını, hareketlerimizi sınırlandırdığını, bize görünür/görünmez baskılar yaptığını ifade ederek, bu olumsuzluklarla mücadele etmeye giriştĭ̆imizde ise kör duvarlara çarpacağımızı söyler (Freyer, 1963, s. 11). Toplum gerçeğini anlayabilmemiz açısından en önemli noktalardan birisi de her toplumda toplumsal farklılıkların olduğu gerçeğidir. Toplumsal farklılıklar ve tarihi tecrübeler bir milletin geleceğini şekillendiren esas unsurlardandır. Toplumsal sorunlar farklılıklar gösterdiği gibi bu sorunların çözüm yolları da farklılıklar gösterir. Kültürel çalışmalarda kimlik ve farklılık kavramları kapsamında toplumsal farklılıklar incelenmiştir. Buna göre kimlik, ya bireysel olarak ya da toplumsal olarak kendilerinin ne olduğunu düşünen insanların kim olduğunu ve bunun kültürel olarak nasıl kurulduğunu ifade ederken, farklılık ise çeşitli insan kimliği ve deneyim biçimini açıklar. (Smith- Riley, 2016, s. 341)

Zaim'de bu düşünceye katılmaktadır ve ABD'de ki çalışma hayatı üzerinde geliştirilen çözümleri ülkemizde aynen uygulanamayacağını söyler. Aslında bu bakış açısı onu anlamamız için anahtar yorumlardan birisidir. Sosyal ve iktisadi problemlerin çözümünde diğer milletlerin tecrübe birikimlerinden de yararlanılır ancak kalıcı çözümler her milletin kendi sosyolojik gerçekleri doğrultusunda atacağı adımlar sayesinde başarıya ulaşır.

Sabahattin Zaim'in en önemli yanlarından birisi de iktisatçı oluşudur. İslam iktisadi üzerine yapmış olduğu yorumlar son derece önemlidir ancak bu konunun ayrıntılarına burada girilmeyecektir. 1969 yllında MT'TB'de yüksekokul gençliğine Modern İktisat ve İslam başlıklı bir konferans veren Zaim, İslam düşüncesinin iktisadi faaliyetten anladıklarının batı sistemlerinden tamamen farklı 
olduğunu ortaya koymaya çalışmıstır. Çok erken dönemlerde yapmış olduğu bu konuşmasındaki tespitleri yaşamının sonuna kadar devam ettirmiş hatta kuruluşlarında aktif görev aldı̆̆ finans kuruluşlarında somut uygulamalar geliştirmiştir. Zaim’in de aktif rol aldığı bir grup bilim adamı modern dünyada İslam toplumlarının yaşadığı iktisadi sorunları tartışmak ve yeni çözüm yolları bulmak üzere çeşitli ülkelerde iktisat kongreleri düzenlemiştirler. Dünya İslam İktisat Kongrelerinde İslam iktisad1 mefhumu ve metodolojisi, İslam iktisat modelinde tüketim ve üretim, devletin rolü, sigorta, faizsiz bankacılık, zekât uygulaması ve mali siyaset, iktisadi gelişme ve İslam ülkeleri arsında iktisadi işbirliği konuları tartışılmıştır. Zaim, Ferguson’un dediği gibi “eğer son dört bin yıl düşünen insanın yükselişine şahitlik ettiyse, şu anda bankacılık yapan insanın yükselişine tanık olmaktayız” (Ferguson, 2012, s. 11) ifadesini anlamış ve başta faizsiz bankacılık olmak üzere bu alanda birçok çalışma yapmıştır.

Sabahattin Zaim bir iktisatçı olarak insan ihtiyaçlarını maddi ve manevi ihtiyaçlar olarak ikiye ayırabileceğimizi, bunlardan birincisi olan manevi ihtiyaçların dil, din, örf ve musiki gibi çeşitli unsurlardan oluştuğunu belirtir. Maddi ihtiyaçları ise gida, barınma, giyinme, sağlık, eğitim ve güvenlikten müteşekkil olduğunu söyleyen Zaim, temel ihtiyaçların mahiyetinin değişmeyeceğini buna mukabil ise maddi ihtiyaçları karşılayan vasıtaların çeşitlerinin ve şekillerinin değişeceğine inanmaktadır. Günümüz dünyasında meydana gelen değişimler temel maddi ihtiyaçları karşılayan vasıtaların çeşitlenmesinden ibaret görür ve maddi sahadaki medeniyeti geliştiren sürecinde teknoloji olduğunun altını çizer. (Zaim, 2007, s. 111)

Modern insan ve modern batı medeniyeti, İnsanın maddi ihtiyaçlarını karşılayan vasıtaların çeşidi, şekli, estetiği ve rengi güzelleştikçe medeniyetin değişeceğine inanmaktadır. Oysa Zaim’e göre, medeniyetin insan unsuru olmadan değişimi yüzeysel bir değişimdir. İslam medeniyeti kendine has Özellikleri olan, tevhit inancı ile şekillenmiş, İslam ahlak ve esaslarını yaşam esasları haline getirmiş, tasavvufi kültürle beslenmiş insanın batılı insandan ayrıştıran temel özellikleri olduğuna inanır.

Ona göre, dünya sistemi ne liberalist ne de komünist sistemlere mahkûm değildir. İslam toplumlarındaki münevverler, İslam ahlakı esaslı bir iktisadi nizam inşası ile modern insanın yaşamakta olduğu derin anlam krizleri ile baş edebilecektir (Zaim, 2007, s. 573, c.3). Kapitalist sistemin, insanlar1 aşırı tüketime alıştırdığını, tüketme güdüsünü kontrol edemeyen bireyin ise bir müddet sonra mutsuz olduğunu birçok saha araştırması ortaya koymaktadır. Batılı toplumlarla batılı olmayan toplumların tüketim kültürleri ve tüketim alışkanlıkları arasında bulunan farklar, birbirlerinden farklı toplumsal yapıların bir sonucudur. Ancak kapitalist sistem küreselleşme olgusunun da bir sonucu olarak dünyada yaşayan insanları tek-tipleştirmektedir. Küresel şirketler, çevrimiçi satış sistemleri ve bu süreçleri besleyen birbirleri ile bütünleşik karar alma mekanizmaları sıradan bireylerin bütün tercihlerini yönlendirmekte, insanların yaşam biçimlerinden inanç sistemlerine kadar yaşam alanlarının tamamına örtülü/örtüsüz müdahale etmektedir.

\section{Modern Eğitim Sistemlerinin Kurulması ve Kurumsallaşması}

Sabahattin Zaim'in gerek orta öğrenimine gerekse yükseköğrenimine baktığımızda iyi bir eğitim aldığını görmekteyiz. 1940’lı yıllarda Vefa Lisesinde eğitim almıştır. Bu yıllara ait eğitim hayatının şekillenmesinde önemli olan bir hatırası vardır. Hasan Ali Yücel’in Milli Eğitim Bakanı olduğu yıllarda Arapça ve Farsça eğitimin yerine klasik şube adı altında açılan sınıflarda Latince ve Yunanca dersi 
verilmesi kararlaştırılır. Pilot uygulama olarak Türkiye'de üç okul seçilir ki bu seçilen okullardan birisi de Zaim'in okumakta olduğu Vefa lisesidir. Diğer iki okul ise biri Galatasaray Lisesi diğeri de Ankara'da Gazi lisesidir. Klasik sınıflarda verilecek eğitim dönemin bakanı tarafından önemsendiği için bu programlar okullarda sınırlı sayıda seçilecek çalışkan öğrenciler için planlanmıştır. Vefa Lisesinde bu dersleri almak için seçilen 40 öğrenciden birisi de Sabahattin Zaim’dir (Zaim, 2008, s. 82). Modernleşme çabalarının hızla sürdüğ̈̈ bu yıllarda liselerde Latince ve Yunanca ders koymanın dayandığı temel saik, Avrupa modernleşmesinin hümanizma ile başlaması ve bu hümanizma akımına da Helenizmin kaynaklık ediyor olması yatmaktadır. İnalcık, modern Avrupa'nın öteki bütün geleneksel medeniyetlerden ayıran ve ona bugüne kadar dünyada üstün bir egemenlik sağlayan fikri hareketin hümanizm olduğunu söyler. $O$, hümanizmin ana kaynağının da düşünce ve sanatta antik Yunan kültürü ve onun değerler sistemini benimseyen Helenizm olduğunu ifade eder. (İnalcık. 2005, s. 9)

Cumhuriyet dönemi değişimlerinde hukuk alanında yapılan köklü değişimlerden sonra en büyük değişim eğitim alanında yapılmıştır. Osmanlı eğitim sistemi yerine batılı eğitim sistemi benimsenmiş, ilk iş olarak da eğitimin birleştirilmesi ve modernleştirilmesi üzerine yoğunlaşılmıstır. 1924'te çıkarılan Tevhid-i Tedrisat Kanunu ile bütün eğitim-öğretim faaliyetleri Milli Eğitim Bakanlığı'na devredilmiştir. 1928'de devletin bir dini olduğu maddesi Anayasa'dan çıkarıldıktan sonra 1930'da şehir okullarında, 1933'de ise köy okullarında olmak üzere din dersleri kaldırıldı. Arapça ve Farsça ibareler yerine yeni kelimeler türetildi ve eğitim hayatında bu kavramlar kullanılmaya başlandı. Cumhuriyetin kuruluş yıllarında ve günümüzde de hala sürmekte olan en büyük kavga din eğitimi ve öğretimi üzerinden sürmektedir. Türkiye'nin normalleşmesi için bu konunun gündemden düşerek, mevcut uygulamaları halkın istekleri doğrultusunda güncellemekte fayda vardır. Sabahattin Zaim de böyle düşünmektedir. Türk toplumu, özellikle din eğitimini, devlet eliyle ve devletin yetkili kurumları aracılığıyla almadığı takdirde bu açı̆̆ını bir şekilde tamamlama yoluna gidecektir. Dolayısıyla devlet, milli eğitim sistemine entegre bir şekilde, kendi vatandaşlarının dini inançlarını özgürce öğrenebilmeleri için tüm kanalları sonuna kadar açmalıdır. Zaim ve arkadaşları, devletin din eğitimine sıcak bakmadığı, hatta yasakladığı yıllarda, milletin din eğitimine katk1 sağlamak amacıyla kuruluşunda aktif yer aldığı İlim Yayma Cemiyetini de burada hatırlamakta fayda vardır. Cumhuriyetin kuruluş yıllarında, günümüze göre daha radikal biçimde uygulanan laiklik politikaları, devletle dini ayırmak değil, dini devlet tarafindan tamamen kontrol altında tutmak şeklinde uygulanmıştı. Bu uygulama biçimine halk kitleleri tarafindan görünür tepkiler ortaya konulduğu gibi görünmeyen sivil itaatsizlik örneklerine de rastlamak mümkündür. (Davison, 2010, s. 214)

06.01.1997 tarihinden 20.05.1998 tarihine kadar YÖK üyeliği de yapmış olan Zaim Türkiye’de birçok üniversitenin kuruluşunda görev aldığ1 gibi Pakistan ve Malezya'da kurulan İslam Üniversitelerinin kuruluşlarında aktif rol almıştır. Uluslararası Saraybosna Üniversitesinin de kurucuları arasında olan Zaim'in bu davranışı, sadece Türkiye değil, geniş İslam coğrafyasının tamamında topyekûn bir eğitim seferberliğine olan inancını göstermektedir. İslam toplumları başta olmak üzere Türk toplumunda da eğitim eksikliğinden dolayı bir geri kalmışlık ya da batılı anlamda modernleşmenin mümkün olmadığına inananların sayısı bir hayli fazladır. Aslında bu düşünce kendi içerisinde eksiklikler barındırsa da sorunun ana kaynağı olduğu açıktır. Ancak batı ile olan münasebetimizde, onların 
yakalamış oldukları yaşam standartlarını ve üretkenliklerini yakalamamız için gerekli olan eğitim sisteminin ne’liği ve nasıllığ1 konusunda kafa karışıklığ1 sonuca ulaşmış değildir.

Zaim'e göre, Türk eğitim sisteminin en büyük çıkmazı, kendi sosyal dinamiklerine uygun bir eğitim müfredatını ortaya koyamamasıdır. Toplumsal yapıya uygun bir müfredat ortaya konulamadığ için Batılı eğitim modelleri aynen taklit edilerek uygulamaya konulmuş ancak Batıdaki başarı yakalanamamıştır. Zaim’e göre "biz Müslüman olduğumuz için ne batının felsefesini (çünkü Hristiyanlıkla birleşmiş bir Batı medeniyeti var) ne de kendi sistemimizi” kurmamış olduğumuzdan eğitim sistemi gençlĭgi mana, istikamet ve ideal bakımdan yetersiz birakmıştır (Zaim, 2007, s. 16). Eğitim sisteminin milli ve yerli olması bütün toplumların bir hedefidir. İletişim teknolojilerinin çok hızlı bir biçimde ilerlemesi, toplumlar arasındaki etkileşimin öngörülemez biçimde değişikliğe uğraması, toplumsal kurumların ve toplumsal yapıların hızlı bir şekilde değişmesi gibi nedenlerden dolayı eğitim sistemlerinin evrenselliği de tartışılmaya başlanmıştır. Türk muhafazakârlı̆̆ının eğitim sisteminin milli ve yerli değerler üzerinden inşa edilmesi gerektiğine dair 1srarlı vurgusunu Zaim'de de görebiliriz. Bu görüşün en 1srarlı savunucularından biri olan ve muhtemelen Zaim'in düşünce dünyasına da ciddi etkileri olmuş olan Nurettin Topçu "Maarif Davamız" adlı eserinde Osmanlı'dan beri sürmekte olan kötü gidişin en büyük nedeninin kültür ve eğitim hayatında aranması gerektiğini ifade eder. (Topçu, 1997, s. 11)

Sabahattin Zaim'in geniş manada İslam toplumları, dar manada ise Türk milleti için önerdiği eğitim modelinin üç büyük çıktısı olması gerektiğini düşünür. Ona göre, eğitim sistemi gençleri mana, istikamet ve ideal bakımdan beslemelidir. Bu düşüncelerini hayata geçirmek amacıyla hem Türkiye'de hem de çeşitli İslam ülkelerinde somut çalışmalar yapmak için 1977'de Mekke'de yapılan İslami Eğitimde Birinci Dünya Kongresinin düzenleyicileri arsında Zaim’de vardır. İslami eğitim kavramının prensipleri, gayesi ve metodolojisi, bu prensiplerin somut uygulamaya nasıl geçileceği ve İslam alimleri içerisinde fikir ve işbirliğinin nasıl yapılacağı konuları ele alınmıştır. Bu toplantılar sonucunda İslam eğitiminin gayesi başta ilim kollarını yeniden tasnifi, müfredatlarınca tanzimi, Arapça öğrenimi, bayanların eğitim hayatı içerisinde yer alması, azınlıkların eğitimi ve misyonerlik faaliyetlerinin engellenmesi olarak belirlenmiştir. İslam dünyasında eğitim seferberliği İslam dünyasının geri kalma sorununu çözmeyi ana hedef olarak belirlemiştir. Çünkü sorunun kaynağının doğru biçimde saptanamaması çözümün de nasıl olacağı hususunda belirsizliklere neden olmuş, bu sorunları aşacak toplumsal güç ve kesimleri de ne yapacakları konusunda şaşkın bırakmıştır. (Sezer, 1998, s. 40)

\section{Sonuç olarak}

Son yüz yıllık tecrübelerimiz göstermiştir ki muhafazakârlık ve modernleşme arasında ters bir ilişki olduğunu düşünenler yanılmıştır. Toplumda muhafazakâr eğilimler arttıkça modernleşmenin azalacağını ya da modernleşme eğilimleri arttıkça muhafazakârlığın azalacağını düşünenler gerçeği ıskalamıştır. Modernleşme ve muhafazakârlık arasındaki ilişkide her toplum ve her çağ için geçerli asimetrik bir ilişkinin kurulamayacağ görülmüştür. Her iki eğilimin de yaşadığ1 toplumsal şartlar ve tarihsel koşullar sonucunda değişim gösterdiği, kendi duruşunu yeniden gözden geçirdiği, söylem ve eylem değişikliklerine gittiği açıktır. Türk muhafazakârlığının tipik bir örneği olarak incelemeye çalıştığımız Sabahattin Zaim’in yaşamı da muhafazakârlık ve modernlik arasında kurduğumuz bu 
olumlu ilişkiyi destekler mahiyettedir. Zaim’in gerek akademik nosyonu gerekse eğitim süreci incelendiğinde, kendini Türk modernleşmesinin taşıyıcısı olduğu iddiasında bulunanlardan daha modern olduğu görülecektir. Yalnız Zaim’in modernliği, 19. yüzyıl batı aydınlanması ile başlayan, 20. yüzyılda pozitivist gelenekle doruğa ulaşan ve 21. yüzyılda kapitalist sistemlerle altın çağını yaşayan batı tarzı modernlikten çok farklı bir tecrübedir. Muhafazakar modernleşme olarak isimlendirilebilecek bu tecrübe, batı dışı toplumlar için, içerisinde çok sayıda önemli detayı barındıran, incelemeye ve üzerinde düşünmeye değer bir modeldir.

Batı tipi, erken modernleşme dönemlerinde yaşanan toplumsal krizler, batı dışı modernleşme tecrübesi yaşayan toplumlarda aynı şekilde tezahür etmemiştir. Batı dışı toplumlar kendi sosyal ve tarihi gerçekliklerini yaşamaya devam etmişler ancak batıyla karşılaştıkları her noktada batı tarafindan kabul görmemiştirler. Bir azgelişmiş toplum özelliŭi ve öykünmecilik olarak yorumlanabilecek bir tutum olarak batı tarafindan takdir görme ve beğenilme arzusu yakın zamanlara kadar Türkiye'de de azımsanmayacak bir grup tarafindan fazlasıyla önemsenen bir durumdu. Sabahattin Zaim ve onun sistematiğini benimseyen muhafazakâr aydınlar açısından doğu-batı arasında ki ilişki batının istediği biçimde sürdürülmemesi gereken bir ilişki biçimiydi. Öyleyse, gelişmekte olan ülkelerin düşünürleri, olduğundan daha fazla sorumluluk alarak doğu-batı arasındaki bu makasın bir biçimde kapatılması gerektiğine inanıyorlardı. Bunun için de batının gerek bilimsel alanda gerekse teknolojik alanda üretmiş olduğu müktesebat maksimum düzeyde yararlanılabilir bir şeydi. Muhafazakâr modernleşmeciler kültür ve medeniyet unsurlarının ise aynen taklit edilmemesi gerektiği noktasında neredeyse hem fikirdiler. Gene Zaim'in hatıratı üzerinden baktığımızda özellikle finans alanında inşa etmeye çalıştığı faizsiz katılım bankacılı̆̆ı modellemeleri ciddiye alınması gereken son derece önemli çalışmalardır. Paranın dolaşımı, ticaret sistemleri, teknolojik modernleşme ürünleri konusunda batıdan gelecek olan yeniliklere son derece açık olan Sabahattin Zaim, batılı kültürel ve ahlaki değerlerin alınmasında da son derece kapalidir.

Sabahattin Zaim olaylar ve olgular karşısında somut öneriler geliştiren, bu somut önerilerini uygulamaya geçiren bir insan olduğunu yaşamıyla ortaya koymuş ender insanlardandır. Zaim, yaşadığımız süreci doğru okumamızı anlatırken şu örneğe göndermede bulunur. Batı toplumları kentleşme olgusuyla birlikte "yalnız kalabalıklar" olarak adlandırılan, bir arada yaşayan insanların, ruhen birbirlerine yabancı kalmalarına maruz kaldıklarını bu sorunu aşmada da yetersiz kaldıklarını söyler. İslam toplumları da gelecekte mutlaka bu süreçten geçecektir. O halde bugünden geleceği görüp, ön görülerimizi ve planlarımızı buna göre yapmalıyız der. "Ahlaki ve kültürel panzehirler" (Zaim, 2007, s. 119) geliştirmenin gerekliliğinden bahseder. 1965'li yıllarda insanlığın yeni bir çağa girdiğini ve bu çağın adının da "topyekûn sanayileşme" çağı olduğunu söyler. 20. yüzyılın ikinci yarısı için doğru olan bu isimlendirme güncelliğini yitirmiş, geldiğimiz süreç 21. yüzyılda bambaşka nitelendirmelerle isimlendirilmiştir. Muhafazakâr modernleşmenin yeni aktörleri 21. yüzyll için yeni söylemlerle yeniden kendi ardıllarını üreteceklerdir. 


\section{KAYNAKÇA}

Ahmad, F. (2007). Bir kimlik peşinde Türkiye. (S. C. Karadeli, Çev.). İstanbul: İstanbul Bilgi Üniversitesi Yayinları.

Berkes, N. (2002). Türkiye’de Çağdaşlaşma. İstanbul: YKY Yayınları. 2. Baskı.

Berger, P. L. (2002). “Sekülarizmin gerilemesi” sekülarizm sorgulanyor. (Hazırlayan: A. Köse). İstanbul: Ufuk Kitaplar1.

Davison, A. (2012). Türkiye'de sekülarižm ve modernlik. (Tuncay Birkan, Çev.). İstanbul: İletişim Yayınları. 3. Bask1.

Einsendtadt, S.N. (2014). Modernleşme başkaldır ve değişim. (U. Coşkun, Çev.). İstanbul: Doğu Batı Yayınları.

Falk, R. (2001). Yırtıcı küreselleşme. İstanbul: Küre Yayınları.

Ferguson, N. (2012). Paranın yükeselişi dünyanın finansal yü̈kselişi. 2. Bask1 (B. Pala, Çev.). İstanbul: YKY Yayınları.

Freyer, H. (1963). Sosyolojizye giriş. (N. Abadan, Çev.). Ankara: Ankara Üniversitesi Siyasal Bilgiler Fakültesi Yayınları.

İnalc1k, H. (2005). Helenizm, Megali idea ve Türkiye. Doğu Batı Dergisi. Y11:8, Say1: 31.

Konya Ticaret Odas1. (2005). Konya ticaretine hizmet edenler. Konya: KTO Yayınlar1.

Mardin, Ş. (2005). Operasyonel kodlarda süreklilik, kırılma ve yeniden inşa: Dün ve bugün Türk islami istisnacilı̆̆1. Doğu Batı Dergisi. Y1l: Say1: 31, Sayfa:29-52.

Sezer, B. (1998). Doğu batı ayrımı. Doğu Batı Dergisi. Y1l:1, Say1:2.

Smith, P.- Riley, A. (2016). Kültürel kurama giriş. Ankara: Dipnot Yayınları.

Topçu, N. (1997). Türkiye'nin maarif davası. İstanbul: Dergah Yayınları.

Zaim, S. (2007). Türkiye'nin yirminci yü̈ynlı toplum/iktisat/siyaset. İstanbul: İsaret Yayınları, Cilt: 1.

Türkiye'nin yirminci yü̈ynl toplum/ iktisat/siyaset. (2007). İstanbul: İşaret Yayınları, Cilt: 2.

Türkiye'nin yirminci yüzynl toplum/ iketisat/ siyaset, işaret yaynlar. (2007). Cilt: 3. İstanbul.

Bir ömrün hikayeleri (1926-2007). (2008). İstanbul: İşaret Yayınları. 